\title{
Boris Johnson to the rescue? How the Conservatives won the radical right vote in the 2019 General Election
}

Article

Published Version

Creative Commons: Attribution 4.0 (CC-BY)

Open access

Evans, G., De Geus, R. ORCID: https://orcid.org/0000-00033053-2123 and Green, J. (2021) Boris Johnson to the rescue? How the Conservatives won the radical right vote in the 2019 General Election. Political Studies Review. ISSN 1478-9302 doi: https://doi.org/10.1177/00323217211051191 Available at https://centaur.reading.ac.uk/100272/

It is advisable to refer to the publisher's version if you intend to cite from the work. See Guidance on citing.

To link to this article DOI: http://dx.doi.org/10.1177/00323217211051191

Publisher: SAGE

All outputs in CentAUR are protected by Intellectual Property Rights law, including copyright law. Copyright and IPR is retained by the creators or other copyright holders. Terms and conditions for use of this material are defined in the End User Agreement.

www.reading.ac.uk/centaur 
Central Archive at the University of Reading

Reading's research outputs online 
Boris Johnson to the Rescue? How the Conservatives Won the Radical-Right Vote in the 2019 General Election
Political Studies

I-22

(C) The Author(s) 2021

(c) (i)

Article reuse guidelines: sagepub.com/journals-permissions DOI: 10.1177/00323217211051191 journals.sagepub.com/home/psx

\author{
Geoffrey Evans' ${ }^{(i D}$, Roosmarijn de Geus ${ }^{2}$ (D) \\ and Jane Green'
}

\begin{abstract}
How can centre-right parties in majoritarian systems adapt to threats from the radical right? Using a long-term inter-election panel study, we identify a remarkably stable constituency of support for Britain's recent radical-right parties - the UK Independence Party and the Brexit Party. We show also how these same voters defected from the Conservatives across elections. In response, the government used a combination of the election of a new leader, Boris Johnson, and a hardline position on Brexit to reincorporate these voters into its support base, helping to lead to a large Conservative majority in 2019. Cross-party evaluations of Johnson were even more important in influencing this success than the issue of Brexit itself. Effective centre-right adaption to radicalright challenges is not simply about strategic issue positioning, it can also derive from centre-right leaders with populist appeal.
\end{abstract}

\title{
Keywords
}

voting, Conservative Party, radical right, Brexit, leader effects

Accepted: 17 September 2021

\section{Introduction}

The rise of a radical-right constituency of voters has impacted substantially on European political systems in recent decades. These systems, with their predominantly proportional forms of electoral representation, have in many instances seen the emergence of niche parties on the right. Typically, such parties have appealed on the basis of anti-immigrant and anti-European Union (EU) positions. In Britain, the rise of the UK Independence Party (UKIP) mirrored this pattern, appealing to voters whose anti-EU and anti-immigrant

\footnotetext{
'Nuffield College, University of Oxford, Oxford, UK

${ }^{2}$ Department of Politics and International Relations, University of Reading, UK

Corresponding author:

Geoffrey Evans, Nuffield College, University of Oxford, Oxford OXI INF, UK.

Email: geoffrey.evans@nuffield.ox.ac.uk
} 
sentiments were not represented by mainstream parties (Goodwin and Milazzo, 2015). By the 2019 election, however, support for UKIP and its successor anti-EU party, the Brexit Party, was effectively ended, at least for the time being. The primary beneficiaries of this electoral elimination were the Conservative Party - the mainstream centre-right party. In this article, we demonstrate how the Conservatives retook the support of these emergent radical-right parties, culminating in its striking electoral success in the 2019 general election.

The analysis reveals the remarkable degree of continuity in the support for UKIP and the Brexit Party, providing insights into the composition and preferences of the radicalright electorate in Britain. Using the British Election Study (BES) Internet panel (Fieldhouse et al., 2020a), we use a unique panel comparison between two second-order elections; the 2014 and 2019 European Parliament elections, and examine the subsequent flow of votes to the June 2017 and December 2019 UK general elections. The successful pursuit of this section of the electorate is important for understanding how the Conservatives were electorally victorious in 2019. The reasons that they were able to do this relate in part to the polarized nature of the Brexit electorate in the context of the British majoritarian system, but also to the popularity with the radical-right constituency of the new British Prime Minister Boris Johnson. While scholarship on mainstream party responses to the radical-right parties and voters has typically focused on strategic policy shifts, we show how the Conservative Party appealed to these voters over time not only through positioning on Brexit, but also through the election of a charismatic leader with populist appeal, thereby providing a novel insight into the conditions that enable effective centre-right competition with radical-right challengers.

\section{The Centre-Right Dilemma}

How should mainstream parties respond to the electoral threat of radical-right parties? This question has risen in prominence with the vote gains of radical-right parties across Western Europe, which has presented a strategic dilemma to mainstream parties used to competing on the formerly dominant economic left-right dimension. Should mainstream parties engage or disengage (Downs, 2012), hold, defuse or adopt (Bale et al., 2010), or take dismissive, accommodative or adversarial strategies (Abou-Chadi, 2016; Meguid, 2005, 2008; Meijers and Williams, 2019)? The risk of disengaging is that challenger parties continue to make electoral in-roads, having gained success by mobilizing on issues largely ignored by mainstream competitors, cross-cutting the dominant left-right dimension of party competition (Adams et al., 2006; Meguid, 2005). The strategic tendency for political parties to adapt their positions in response to the policy positions of political rivals (Adams and Somer-Topcu, 2009) has, however, led to public opinion responsiveness by mainstream parties on questions of Euroscepticism and immigration policy (Williams and Spoon, 2015), particularly when the electoral losses of a mainstream party can be attributed to success of a radical-right challenger (Harmel and Svåsand, 1997).

As a result, mainstream political parties have become more Eurosceptic (Meijers, 2017) and supportive of more restrictive immigration policies (Abou-Chadi, 2016; Van Spanje, 2010; Wagner and Meyer, 2017). In many instances, this has produced electoral benefits (Downes et al., 2021; Downes and Loveless, 2018; Odmalm and Bale, 2015; Pardos-Prado, 2015), but there is a risk when engaging with and accommodating the issues and appeals of radical-right parties that those issues in consequence increase in salience, and such strategies are likely to be less successful when a challenger 
radical-right party has already become trusted and credible on such issues (Meguid, 2005, 2008). Some mainstream centre-right parties, therefore, experience electoral losses from accommodative strategies (Meijers and Williams, 2019) which can also produce '. . . a tension between market liberal and culturally conservative wings' (Odmalm and Bale, 2015: 5). By trying to prevent or reverse losses to the radical right by adopting stronger stances on issues, such as immigration or by bringing radical-right parties into coalition (De Lange, 2012), the centre-right risks alienating more moderate voters at the same as legitimating the views of the radical right

Mainstream centre-right parties are thus presented with a dilemma. They lose votes if they fail to attend to the issues driving radical-right appeal, but they increase the salience of those issues by competing with emergent radical-right parties and risk losing the centre ground. In short, conservative parties may need to consider whether the chances of winning votes by responding to the radical right outweighs the potential risk of losing voters in the centre.

\section{Successfully Accommodating the Radical Right in Britain: The Conservative Case}

In recent years, the Conservative Party has been sent a series of powerful electoral signals by radical-right voters. In the 2014 European Parliament elections UKIP topped the poll (gaining 26.6\% of the vote), while in the 2015 general election UKIP obtained $12.6 \%$ of the vote. The intervening 2017 general election that followed the EU referendum saw UKIP's vote share drop to less than 2\%. However, with the failure to deliver Brexit, the newly formed Brexit Party had an outstanding breakthrough in the 2019 European Parliament (EP) elections, going from non-existence in March to winning the UK's EP elections 2 months later with $30.5 \%$ of the vote and 28 seats. Accommodating and rerecruiting these voters was clearly important for the Conservative Party's ultimate success in December 2019 when the party won a large majority in parliament, having previously formed a coalition government between 2010 and 2015, a majority government in 2015 but with a slim 12-seat majority, and then a minority government in 2017 unable to pass key Brexit legislation.

However, an accommodative strategy requires certain conditions to be met in order to compete successfully with a radical-right party on salient cross-cutting issues on which they have established a stable voter constituency. The case of the British Conservatives shows how an accommodation strategy can produce electoral benefits. The conditions facilitating the effectiveness of this accommodation strategy include both the electoral implications of the divisive issue of 'Brexit' and the crucial role of leadership selection, in addition to policy emphasis and delivery.

\section{The Electoral System and Polarization Over Brexit}

The majority of research into mainstream party strategies and the radical right has been conducted in multi-party systems under proportional representation. In proportional systems, two-dimensional competition provides opportunities and representation for multiple parties and coalitions. In the British majoritarian system, however, challenger parties can erode mainstream parties' abilities to form a convincing majority but they have little chance of obtaining representation themselves. This was the case in the 2015 UK general 
election, which saw the UKIP gain $12.6 \%$ of the popular vote but only one MP (a former Conservative who had defected to UKIP while in situ).

In such majoritarian systems, median voter theory applies when political competition is unidimensional (Downs, 1957). However, once a second or further dimension becomes relevant, the strategy for obtaining electoral victory becomes considerably more complex. At the very least, it involves a party minimizing distance on one dimension while occupying a winning position on another (Adams et al., 2005; Laver and Sergenti, 2011). When one or more of these dimensions are strongly polarized, involving intense preferences on either side (e.g. twin-peaked rather than single-peaked distributions of preferences), an effective strategy is also likely to involve targeting appeals to one side or other of the division (Rabinowitz and Macdonald, 1989).

Clearly, public opinion on Britain's exit from the EU was heavily polarized (Hobolt et al., 2021), as is illustrated by the strong political identities formed around 'Leave' and 'Remain' (Evans and Schaffner, 2019). Given the strength of this Brexit division among voters, a second dimension of party competition in British politics increasingly dominated electoral choice (Fieldhouse et al., 2020b). The consequence of such a polarized electoral system is that there was little prospect in 2019 of the Conservatives reaching out to obtain new support from Remainers. They instead chose to maximize their appeal to voters on one side of the new identity-basis of competition: Leave voters. They were able to do so in part by advocating a credible commitment to implementing Britain's departure from the EU - 'Get Brexit Done' - but also in no small part because of the election of a new party leader in the summer of 2019.

\section{Leader Appeal}

It has been argued that 'the charismatic bond between leader and follower is absolutely central to populist parties' (Albertazzi and McDonnell, 2008: 7). ${ }^{1}$ Voters supposedly come to see parties of the populist radical right through the lens of their leaders, who have a 'homogenizing' effect on party image (Eatwell, 2018). Consistent with this in the British case, the 'Farage effect' was found to be of considerably greater importance for UKIP voting than the effects of other leaders on voting for their parties (De Geus et al., 2021; Evans and Mellon, 2015).

Nonetheless, although charismatic leadership has been identified as an important element of challenger party success (Albertazzi and McDonnell, 2008; Michel et al., 2020), little attention has been given to its potential to enable parties of the centreright competing for similar types of voters to be successful. We argue that a populist charismatic leader can also provide success for mainstream parties in competition with such challenger parties. After all, if populist voters are susceptible to the appeals of charismatic populist leaders then it stands to reason that their votes can be obtained by parties other than those on the radical right. In this respect Boris Johnson had the potential to become the Conservatives' key weapon in what turned out to be the almost complete electoral annihilation of the highly threatening though ultimately transient Brexit Party.

Much of Johnson's electoral impact appears to have taken place quite quickly after being elected Prime Minister. A poll of polls showed that the Conservative and Labour Parties were more or less equal in mid-July at the time of the Conservative leadership election. ${ }^{2}$ Johnson was elected on 24 July and a change immediately became apparent. By mid-August, the Conservatives were 8-9 percentage points ahead of Labour and this lead 
was stable from then onwards. This suggests that most of the 'leader effect' resulting from Johnson's appointment as Prime Minister occurred because of his election, rather than being built during his time in office. Even following the Brexit Withdrawal Agreement with the EU on 17 October the Conservative lead was only 11 percentage points. By the election on 12 December it was 12 points. Clearly, there was a boost around the time of the Withdrawal Agreement but there was also a far larger boost that came with Johnson's appointment. This, we will demonstrate, was associated with his specific cross-party appeal to the Brexit Party supporters the Conservatives needed to attract: Britain's own radical-right constituency; an exceptionally consistent and stable constituency spanning UKIP's vote in the 2014 European Parliament elections through to the Brexit Party vote in June 2019.

\section{Characterizing the British Radical Right: The Brexit Party as UKIP 2.0}

Many scholars (see Art, 2011; Dolezal, 2012; Ford and Goodwin, 2014) have characterized UKIP as a radical-right party: that is, nativist, authoritarian and populist (Mudde, 2007; Muis and Immerzeel, 2017; Norris and Inglehart, 2019). Examinations of the social bases of support for UKIP have focused on economic disadvantage (the left-behind thesis, for which see Ford and Goodwin, 2014; Rydgren, 2008), their appeal to the selfemployed (Evans and Mellon, 2016), traditional cultural values (Bornschier and Kriesi, 2013; Norris and Inglehart, 2019) or concern about immigration (Dennison and Goodwin, 2015; Evans and Mellon, 2019; Evans and Tilley 2017). The emergence of UKIP with its mainly former-Conservative support-base during the first few years of the early 2010s, culminated in their becoming the winning party in the UK's 2014 European Parliament elections and achieving $12.6 \%$ of the votes at the 2015 general election. Like many other radical-right niche parties, the pro-EU consensus among mainstream parties had opened up space for this Eurosceptic party to obtain support (de Vries and Edwards, 2009; de Vries and Hobolt, 2012), in large part through its credibility on the increasingly important issue of immigration concern among the British public (Dennison and Goodwin, 2015; Evans and Mellon, 2019; Goodwin and Milazzo, 2015).

The first empirical issue we address is whether the 2019 Brexit Party was simply UKIP 2014 revisited - a radical-right party representing views that had been excluded from the political mainstream - or whether there were important differences in the two parties' support bases and appeal to voters. This continuity is central to understanding the party's electoral threat to the Conservatives, and the Conservative response to it. It could be expected that with the same leader (Nigel Farage), and a similarly anti-EU agenda, the Brexit Party appealed to similar sources of support as UKIP. To examine this question, we compare socio-demographic and attitudinal bases of support for UKIP and the Brexit Party, using the BES panel study that uniquely covers both the 2014 and 2019 European Parliament elections; the elections where, respectively, UKIP and the Brexit Party saw their greatest success.

We estimate demographic and attitudinal influences separately so as not to over-control for their association (including a full model in the online appendix, Table A3). The dataset is the BES Internet panel (Fieldhouse et al., 2020a), waves 2 and 16, each the post-European Parliament election waves. Variable information (except for core demographics, which are included in the online appendix and are all coded as standard) is provided in Table 1. 
Table I. Variable Information."

\begin{tabular}{|c|c|c|}
\hline Variable & Survey Question & Coding \\
\hline $\begin{array}{l}\text { Household } \\
\text { finances }\end{array}$ & $\begin{array}{l}\text { How does the financial situation of your } \\
\text { household now compare with what it was } \\
12 \text { months ago? }\end{array}$ & $\begin{array}{l}\text { Got a lot worse to got a } \\
\text { lot better ( } 5 \text { point). Don't } \\
\text { know = missing }\end{array}$ \\
\hline Englishness & $\begin{array}{l}\text { Where would you place yourself on this } \\
\text { scale, where } 0=\text { not at all English, } 7=\text { very } \\
\text { strongly English }\end{array}$ & $\begin{array}{l}\text { Don't know coded to mid- } \\
\text { point }\end{array}$ \\
\hline $\begin{array}{l}\text { European } \\
\text { Integration }\end{array}$ & $\begin{array}{l}\text { Some people feel that Britain should } \\
\text { do all it can to unite fully with the } \\
\text { European Union. Other people feel that } \\
\text { Britain should do all it can to protect its } \\
\text { independence from the European Union. } \\
\text { Where would you place yourself on this } \\
\text { scale? } 0=\text { unite fully with the European } \\
\text { Union, } 10=\text { protect our independence. }\end{array}$ & $\begin{array}{l}\text { For the UK Independence } \\
\text { Party } 2014 \text { models (W2) } \\
\text { responses to two separate } \\
\text { European Union-unification } \\
\text { question were combined (see } \\
\text { footnote). } \\
\text { Don't know coded to mid- } \\
\text { point }\end{array}$ \\
\hline Immigration & $\begin{array}{l}\text { Do you think immigration is good or bad } \\
\text { for Britain's economy? And: Do you think } \\
\text { that immigration undermines or enriches } \\
\text { Britain's cultural life? }\end{array}$ & $\begin{array}{l}\text { Scales range } I-7 \text { and are } \\
\text { combined. Don't know coded } \\
\text { to mid-point }\end{array}$ \\
\hline Redistribution & $\begin{array}{l}\text { Some people feel that government should } \\
\text { make much greater efforts to make } \\
\text { people's incomes more equal. Other people } \\
\text { feel that government should be much } \\
\text { less concerned about how equal people's } \\
\text { incomes are. Where would you place } \\
\text { yourself on this scale? } \\
0=\text { government should try and make } \\
\text { incomes equal, I } 10=\text { government should be } \\
\text { less concerned about equal incomes }\end{array}$ & $\begin{array}{l}\text { Don't know coded to mid- } \\
\text { point }\end{array}$ \\
\hline $\begin{array}{l}\text { Leadership } \\
\text { evaluations }\end{array}$ & $\begin{array}{l}\text { How much do you like or dislike the } \\
\text { following party leaders? David Cameron; } \\
\text { Theresa May; Jeremy Corbyn; Nigel Farage; } \\
\text { Boris Johnson. } \\
0=\text { strongly dislike, } 10 \text { = strongly like }\end{array}$ & $\begin{array}{l}\text { Don't know coded to mid- } \\
\text { point }\end{array}$ \\
\hline $\begin{array}{l}\text { Satisfaction UK } \\
\text { Democracy }\end{array}$ & $\begin{array}{l}\text { On the whole, how satisfied or dissatisfied } \\
\text { are you with the way democracy works in } \\
\text { the UK? }\end{array}$ & $\begin{array}{l}\text { Very dissatisfied to } \\
\text { Very satisfied (4 point). Don't } \\
\text { know }=\text { missing }\end{array}$ \\
\hline
\end{tabular}

Figure 1 presents the likelihood of supporting UKIP in 2014 or the Brexit Party in 2019 for different socio-demographic groups. These estimates are obtained from multivariate models shown in online appendix Table A1. ${ }^{3}$

With the exception of household finances, the two parties are noticeable for the social similarity of their support base. Age and education dominate with support for both parties being drawn from older and less educated groups, with Brexit Party voters older, on average. Age has the largest net effect, with education's effect likely to be more strongly 'cultural' in character than resource-related. ${ }^{4}$ We also see in Figure 1 the commonly observed propensity for men to be more supportive of radical political parties than 


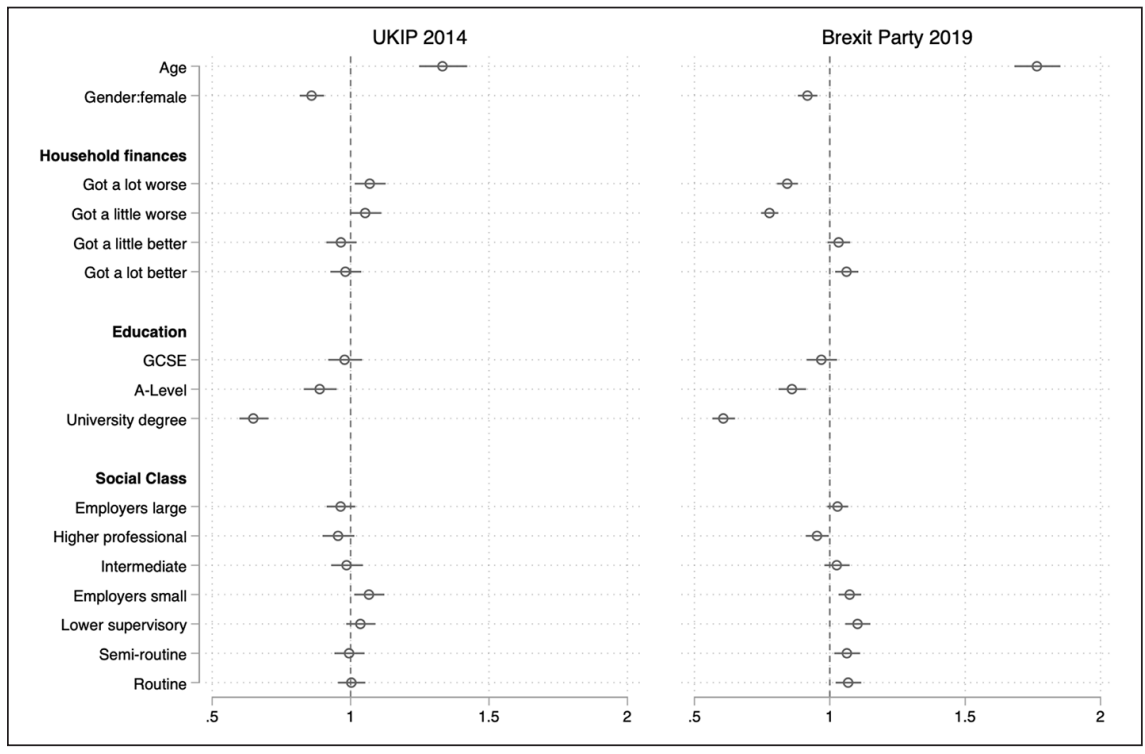

Figure I. Coefficient Plot: Demographic Predictors of UKIP (2014) and Brexit Party (2019) Vote in European Parliament Elections

Education baseline $=$ no qualifications $/$ below GCSE, class baseline $=$ lower professional $/$ managerial . Coefficients are odds ratios, variables are standardized. Error bars are $95 \%$ confidence intervals.

women. A similar shared appeal is seen among 'small employers and the self-employed' - a long-established heartland for the radical right. There are some differences, however: the lower supervisory class is pro-Brexit Party but not pro-UKIP. Interestingly, although there are modest positive effects of declining household finances on UKIP support there are negative coefficients for the Brexit Party, indicating that respondents perceiving a decline in household finances were less likely to vote for the Brexit Party. ${ }^{5}$ In general, the demographic analysis is consistent with previous research (see, e.g. Evans and Mellon, 2016; de Geus et al. 2021) indicating, contrary to some assertions (e.g. Ford and Goodwin, 2014), that radical-right support is not composed primarily of the economically 'leftbehind'. The general pattern is one of similarity between the socio-demographic bases of support for the two parties.

This overall similarity can easily be understood when we examine the flow of the vote between the 2014 and 2019 European Parliament elections using the two post-EP election waves of the BES panel surveys (Fieldhouse et al., 2020a). This contains respondents who responded to both waves across the 5-year period covering the two European Parliament elections. Figure 2 shows that there is a remarkably high level of overlap between 2014 UKIP voters and 2019 Brexit Party voters: approximately 80\% of 2014 UKIP voters voted for the Brexit Party in the 2019 elections and $68 \%$ of the Brexit Party voters had voted for UKIP in 2014. By comparison, the consistency between the 2014 and 2019 European elections is much lower for the Conservatives and Labour. Only 29\% of 2014 Conservative voters voted for the Conservatives again in 2019 (20\% went to the Liberal Democrats and 37\% to the Brexit Party). The Labour Party does only slightly better: 34\% of their 2014 European Parliament voters stayed with them in 2019, but they lost $12 \%$ to the Brexit Party, $26 \%$ to the Liberal Democrats and $13 \%$ to the Green Party. 


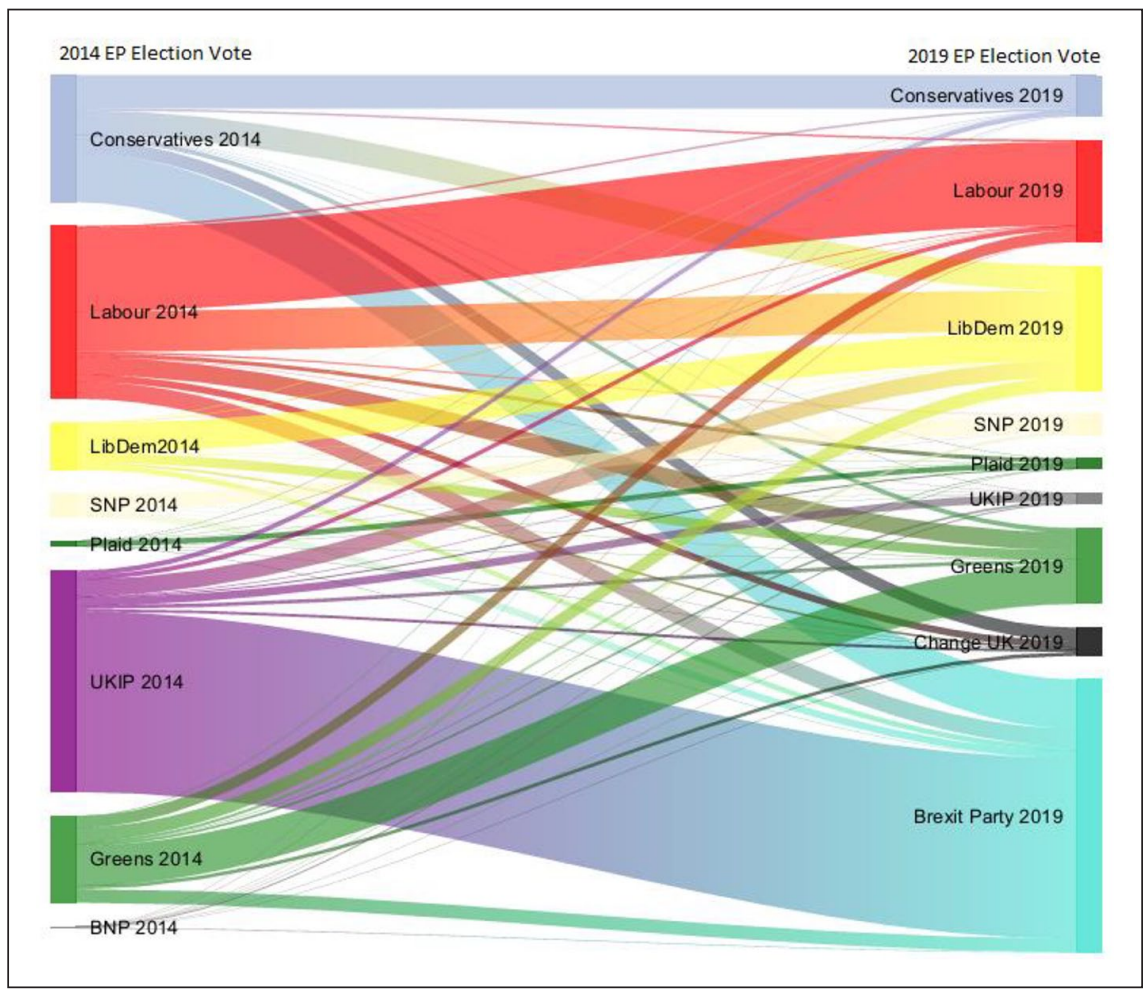

Figure 2. Flow of the Vote Between 2014 and 2019 European Parliamentary Elections. Included are BES Internet panel respondents with a recorded vote choice in both the 2014 and 2019 European Elections. Data are weighted and 'don't know' responses are excluded.

Overall, the Brexit Party took 17\% of its support from Conservative voters in 2014, but only $6 \%$ from former Labour voters.

Figure 2 shows that no other political party had retention and recruitment rates approaching the level attained by UKIP/The Brexit Party across the 5-year period between the two European Parliament elections. ${ }^{6}$ In a period of otherwise dramatic electoral volatility (Fieldhouse et al., 2020b), this stability over two second-order elections is considerable, particularly since the Brexit Party had only existed for 2 months prior to the 2019 European election, and therefore had little time to garner the support of former supporters of UKIP.

This level of continuity in voting retention suggests perhaps a similar pattern of 'more of the same' for voters' motives for supporting them. To examine this, Figure 3 displays results of regression models of UKIP and Brexit Party support on voters' attitudes and perceptions (based on models in online appendix Table A2). These include English nationalism, disapproval of immigration, attitudes towards redistribution (to examine the economic dimension), EU attitudes, leader evaluations and dissatisfaction with democracy. ${ }^{7}$ These scales capture the typical range of concerns and motivations associated with radical-right party voting, including the extent to which support for the radical right reflects a general frustration with politics, a commonly cited reason for radical-right support (Mudde, 2007; Zhirkov, 2014). 


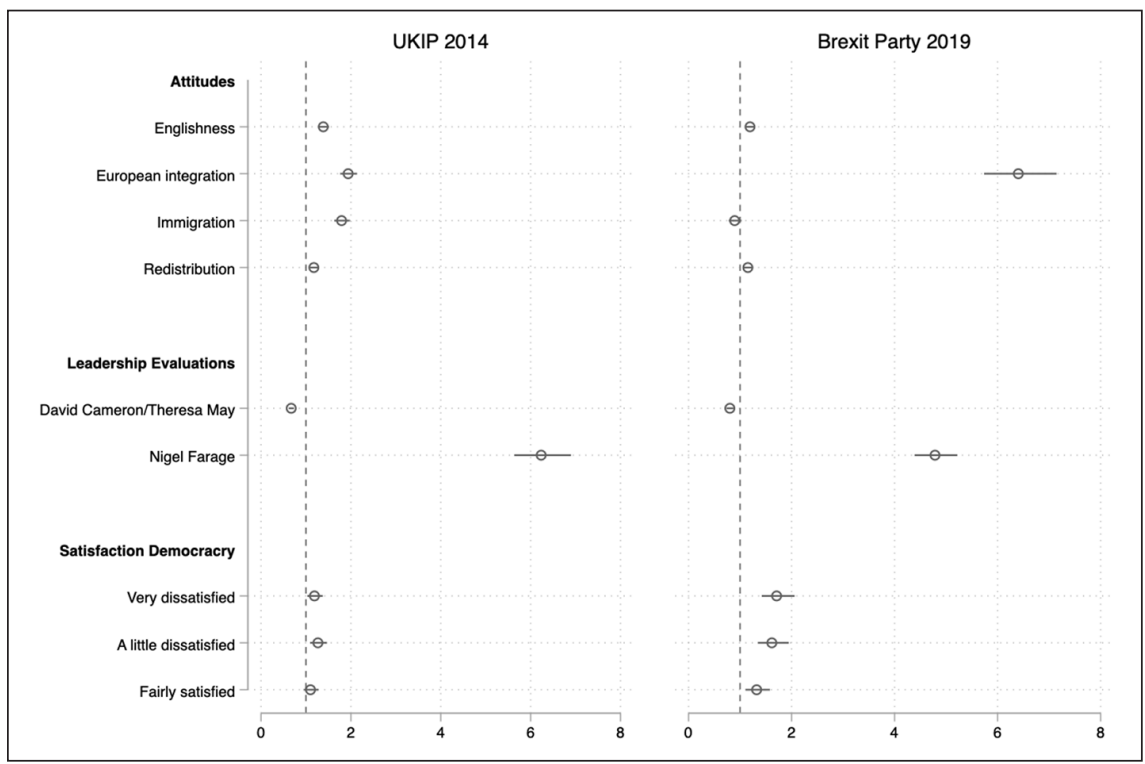

Figure 3. Coefficient Plot: Attitudinal and Perceptual Predictors of UKIP (2014) and Brexit Party (2019) Vote in European Parliament Elections.

Higher values reflect greater anti-immigrant sentiment, anti-redistribution attitudes, a more negative view of European integration and positive approval of party leaders. The democratic satisfaction base category=very satisfied. Coefficients are odds ratios; variables are standardized.

Unprecedented political events had taken place between the 2014 and 2019 European elections. Britain had voted in a referendum on EU membership, that referendum result had failed to secure the outcome for Brexit, another general election had been held to secure a majority for the Conservative government to deliver Brexit, with the outcome being a decline in the Conservatives' parliamentary majority and further legislative and political stalemate. The 2019 European Parliament elections were only conducted in the UK because of a failure of MPs to vote for the Brexit Withdrawal Agreement in Parliament. Thus, while there was considerable demographic similarity in UKIP support in 2014 and Brexit Party support in 2019, the issue of European integration was far more important for Brexit Party support in 2019. Although approval of Nigel Farage is clearly important for both, there are marked differences in the predictive power of the attitude measures in these models. Nationalism and attitudes towards immigration are highly significant predictors of UKIP support, but barely so for the Brexit Party. For the latter, in contrast, attitudes towards the EU dominate other effects. The effect of dissatisfaction with the democratic process also increases substantially. The reasons for these changes are likely to be that (1) immigration has declined in salience as EU immigration has declined in reality and (2) the failure of the government to progress to any exit of whatever form from the EU left a heightened sense of frustration with the workings of parliament, as well as intense opposition to the EU among Brexit Party supporters. There is, then, an attitudinal difference between UKIP and Brexit Party support, notwithstanding their similar demographic base. Support for the Brexit Party in 2019 was more clearly a protest vote against the conduct of politics. The supporters of these two parties were otherwise the same types of voters and to a remarkable degree, the very same people. 
We have thus seen that the Brexit Party support base in 2019 was in effect the same group of voters who had been recruited by UKIP by the 2014 European Parliament elections. We now show how the attempts by the Conservatives to recapture these (primarily former Conservative) voters shaped the ensuing competition for votes in both of the general elections that followed these EU Parliament elections.

\section{The Conservative Party's Response to the 2014 European Parliament Election}

Following the 2014 European Parliament election, the Conservatives won the 2015 general election with the promise of holding a referendum on EU membership. After the 2016 referendum result (with $52 \%$ of the voting population opting to 'leave') the Conservative Party was in a position to appeal to 2014 European Parliament (and 2015 general election) UKIP supporters by taking hold of the issue of EU immigration. By backing 'Brexit', the UK could also exert controls over immigration. Prior to the referendum outcome, there was very little likelihood that any UK government could control EU immigration, at least not without leaving the EU - not then a policy any of the mainstream parties endorsed. Following the referendum, however, Theresa May was able to play the hard Brexit card (Evans and Menon, 2017) and as a result appeal very effectively to UKIP voters who, as we can see in Figure 4, moved en masse to the Conservatives in the ensuing 2017 general election.

This successful appeal prevented a clear defeat for the Conservatives following an otherwise disastrous election campaign in 2017 (Mellon et al., 2018). Its consequence, however, in combination with the realignment of an electorate split by Brexit (Cutts et al., 2020; Fieldhouse et al. 2020b; Green, 2021), was that the Conservatives became dependent on keeping those voters. This accommodation strategy (Meguid, 2005, 2008) was possible even though UKIP had become the most credible party on immigration (Goodwin and Milazzo, 2015). It took something as dramatic as Brexit - and the implications for the British government's ability to regain control over immigration, as well as more widely, for the Conservative Party to successfully accommodate the concerns of the radical right. Also, the 2017 general election was a first-order election in a majoritarian electoral system. Those radical-right voters who had supported UKIP in the 2014 European parliament elections (a second-order election under a proportional system, see Reif et al., 1997) had moved back to the Conservatives under a system that favours the dominant two British parties. With the ongoing political difficulties of Theresa May's government, which with a reduced majority could not gain parliamentary consent for the Withdrawal Agreement for EU exit, the threat of the radical-right again led to a Conservative Party response.

As Figure 5 shows, the Conservatives lost most of their newly won former UKIP voters to the new Brexit Party in the 2019 European Parliament elections. This yo-yo of support between the radical right in second-order elections, and the mainstream Brexitbacking Conservatives in general elections, coincided first with an absence of Conservative support for Brexit (UKIP in 2014), then with backing Brexit (the 2017 general election), then with failing to deliver Brexit (the Brexit Party in 2019). Although approximately $68 \%$ of 2014 UKIP voters voted for the Conservatives in the 2017 General Election, only 2.5\% voted for them in the 2019 European elections. No less than $88 \%$ moved to the Brexit Party.

The prospects for the Conservatives looked grim following the 2019 EP elections. However, protest voters under a proportional system of elections for the European 


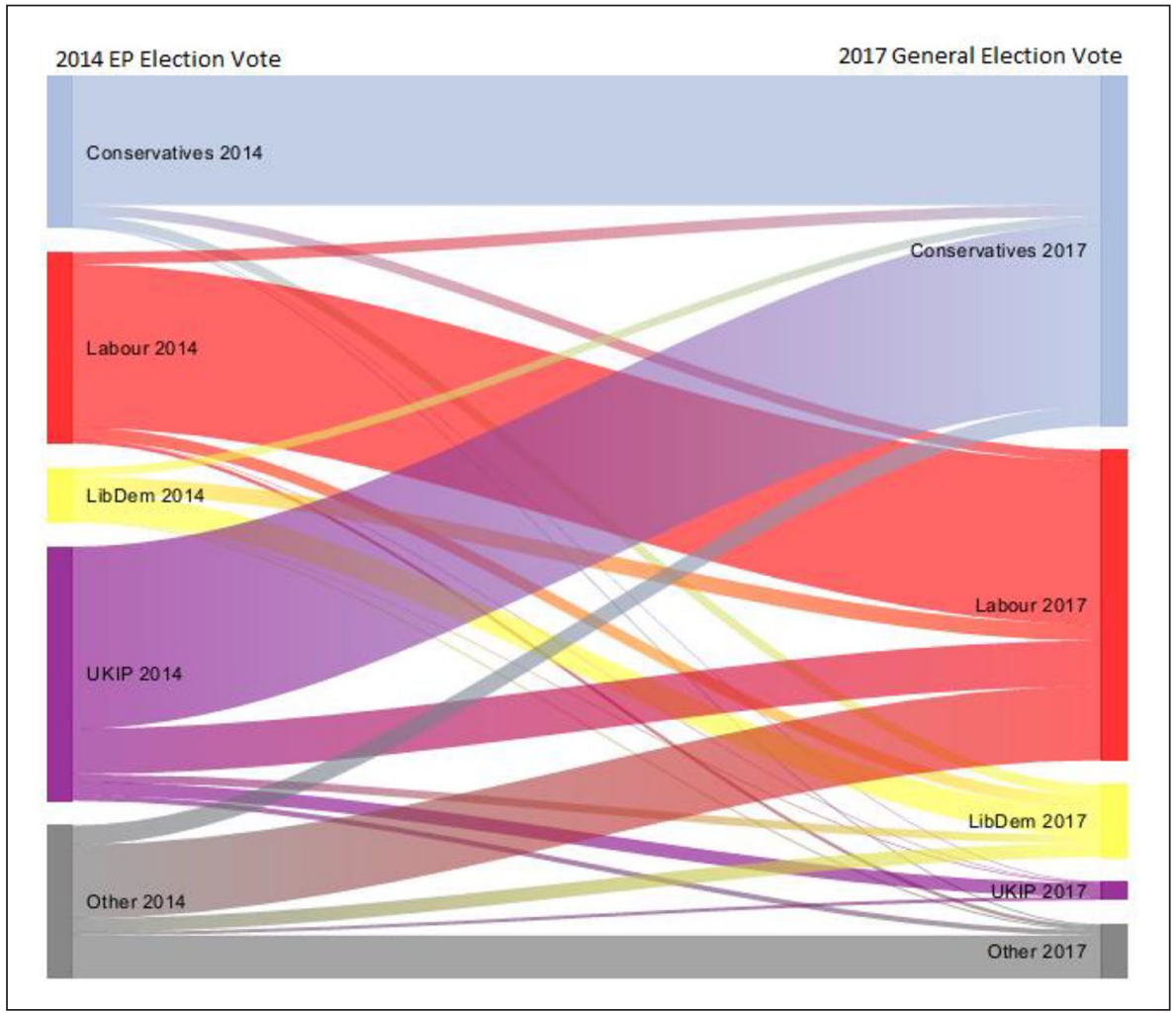

Figure 4. Flow of the Vote: 2014 European Elections to 2017 General Election. Included are BES panel members with a recorded vote choice in all of 2014, 2017 and 2019 elections. Data are weighted, don't know responses are excluded.

Parliament would not necessarily translate into support for these radical-right parties under the UK's majoritarian electoral system for Westminster elections. It could be argued that the Conservatives did not need to heed these voters, and they would simply come back to the Conservatives in a general election when electability became more important under majoritarian rules. However, the electoral threat to the Conservatives from the Brexit Party was higher in 2019 than it was from UKIP in 2014-2015. When asked just after the 2014 European elections, 53\% of BES respondents who voted for UKIP in the European elections stated that they intended to vote for UKIP in a potential general election, $23 \%$ intended to vote for the Conservative Party and $12 \%$ were undecided. When asked the same question in 2019, 64\% of Brexit Party supporters stated they also intended to vote for the Brexit Party in a general election, while only $16 \%$ intended to vote for the Conservative Party and $14 \%$ were still undecided. ${ }^{8}$

\section{The Conservative Party's Response to the 2019 European Parliament Election}

The 2019 European Parliament election result was disastrous for the Conservatives, and indeed marked the lowest ever tally of votes for the two major parties in any European 


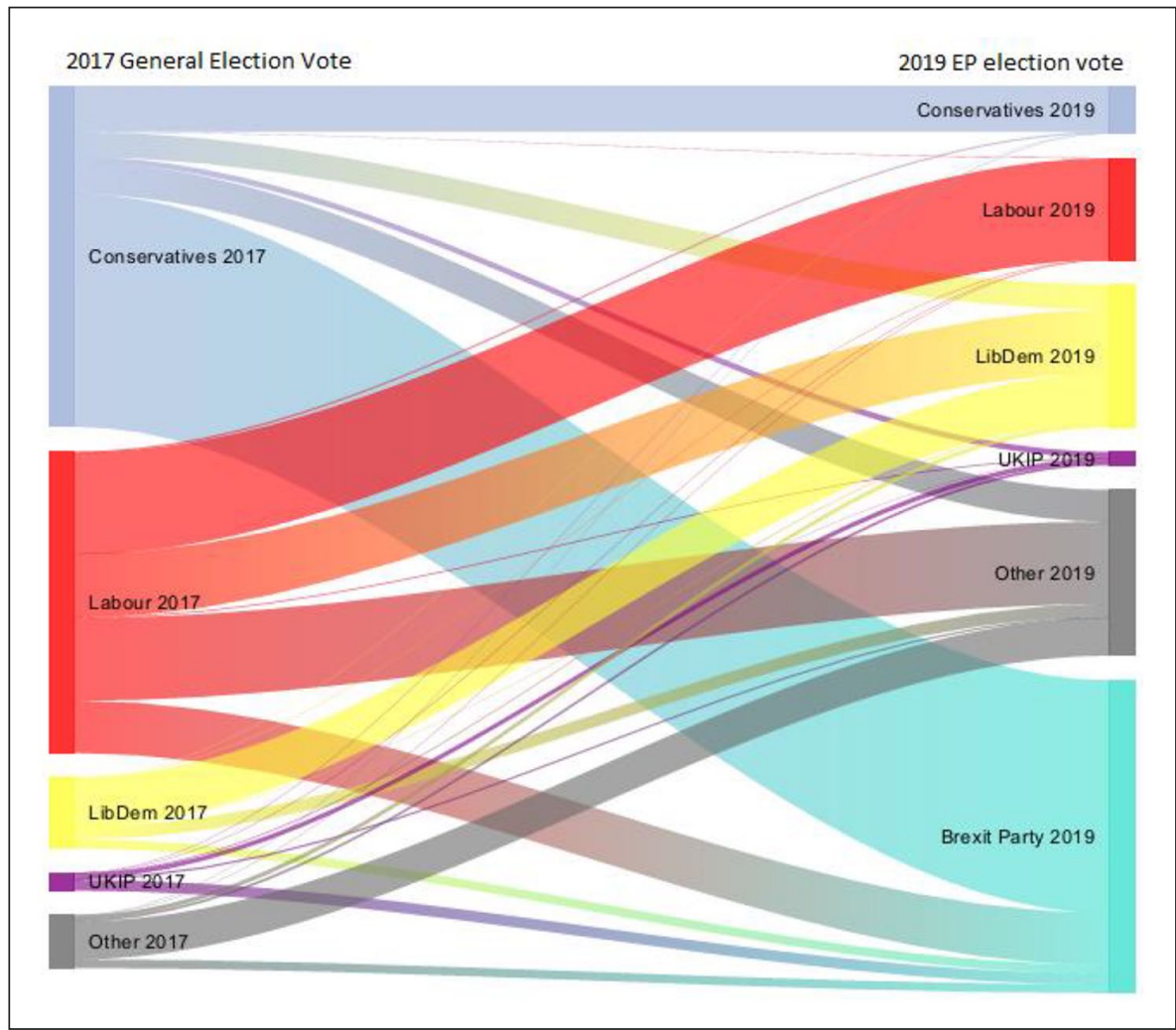

Figure 5. Flow of the Vote Between 2017 General Election and 2019 European Parliament Election.

Included are BES panel members with a recorded vote choice in all of 2014, 2017 and 2019 elections. Data are weighted, don't know responses are excluded.

Parliament election. The sitting party-of-government had come fifth in a major election, securing less than $9 \%$ of the total votes. Prime Minister Theresa May's Brexit Withdrawal Agreement had failed in Parliament three times, and a vote of confidence in her leadership resulted in Prime Minister May resigning ahead of the European Parliament elections, but not effective until afterwards, on 7 June. The Conservatives had gone into national (second-order) elections with a leader about to depart. Her successor, Boris Johnson, took over in July 2019 and had proceeded to call for a general election by October 2019 (which took place on 12 December 2019), to again try to increase the Conservatives' majority to deliver on Brexit. The key difference with Boris Johnson was that he was strongly liked among Brexit Party voters, even before he became Conservative leader. Figure 6 presents the probability of voting for the Brexit Party in the May 2019 European Parliament elections (well before Johnson was elected Conservative leader) by leadership rating. As Figure 6 shows, Johnson was almost as well-liked among European Parliament election Brexit Party voters as their actual, and very popular, leader Nigel Farage, and was substantially more liked than Theresa May.

Given that leadership matters for UKIP/Brexit Party voting, the loyalty of Brexit Party supporters was likely to be severely tested in a general election where Boris Johnson and 


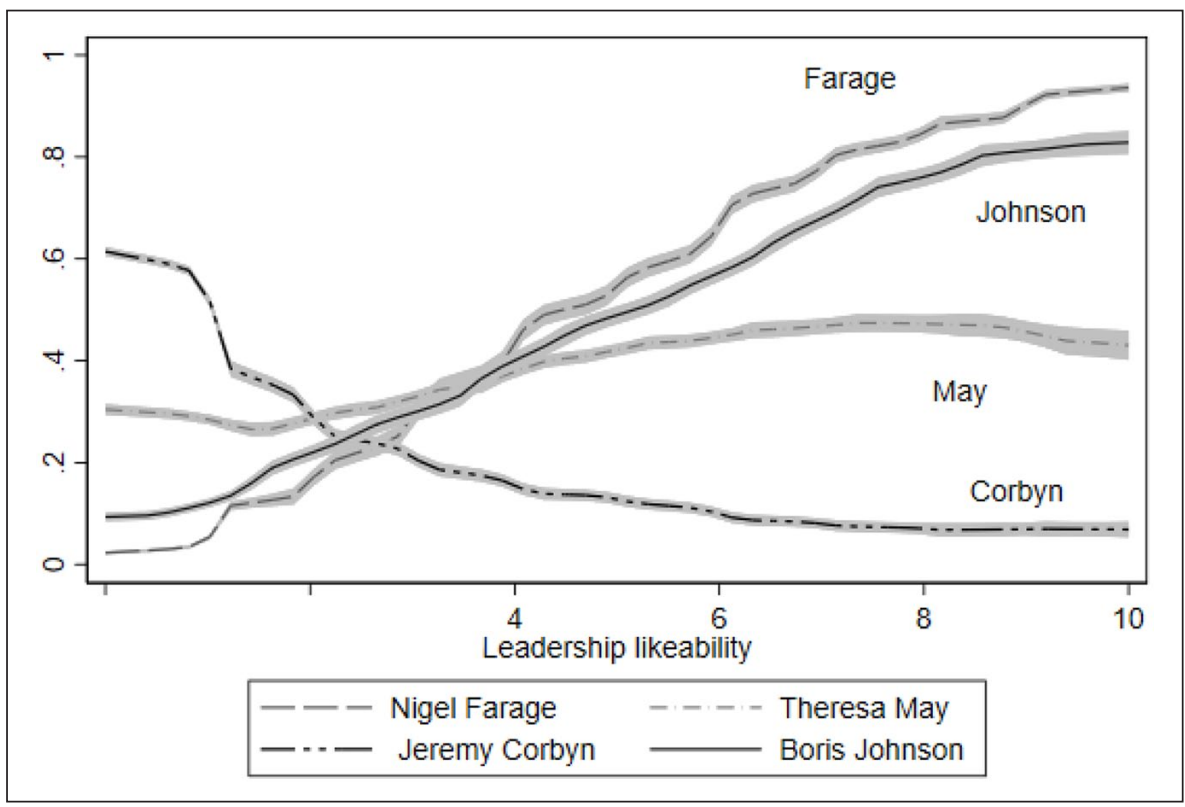

Figure 6. Leader Ratings and Brexit Party Vote in the 2019 EP Election.

Figure shows the probability of voting for the Brexit Party in 2019 European elections ( $y$-axis) by leadership ratings.

not Theresa May was leading the Conservatives. At the same time, Johnson's more hardline approach to the EU may have put off more moderate Conservatives who supported Theresa May. For example, although Johnson was liked far more by European Parliament election Brexit Party voters than May, he was disliked more by European Parliament Conservative voters who had remained loyal to May: Johnson receives only a 4.4 rating from Conservative voters compared to May's score of 6.9. ${ }^{9}$

As Prime Minister he secured a new Withdrawal Agreement with the EU which secured preliminary parliamentary support in its first passage in Parliament, before the general election was called to win a majority for that agreement, and in the Prime Minister's campaign phrase, 'Get Brexit Done'. The Brexit Party stood down candidates except in Labour or other non-Conservative held constituencies. This concerted effort, and Boris Johnson's appeal, was influential in winning back June 2019 Brexit Party voters to the Conservatives in the December 2019 election.

To examine the effect of Johnson on voting for the Conservatives versus the Brexit Party in the 2019 general election we model vote switching between general election vote intention just after the June 2019 EP elections, and reported vote choice after the December 2019 general election, using waves 18 and 19 of the BES Internet panel (Fieldhouse et al., 2020a). Here the baseline is Brexit Party vote intention and the outcome is voting Conservative (or Brexit Party) in December 2019. Figure 7 presents the results (full information can be found in Table A6 in the online appendix).

Figure 7 shows that by far the most substantial predictor of Brexit Party to Conservative Party general election vote switching was the evaluation of Boris Johnson. More Eurosceptic Brexit Party voters were less likely to switch to the Conservatives, but this effect is much smaller than the importance of leadership. Thus, this accommodation 


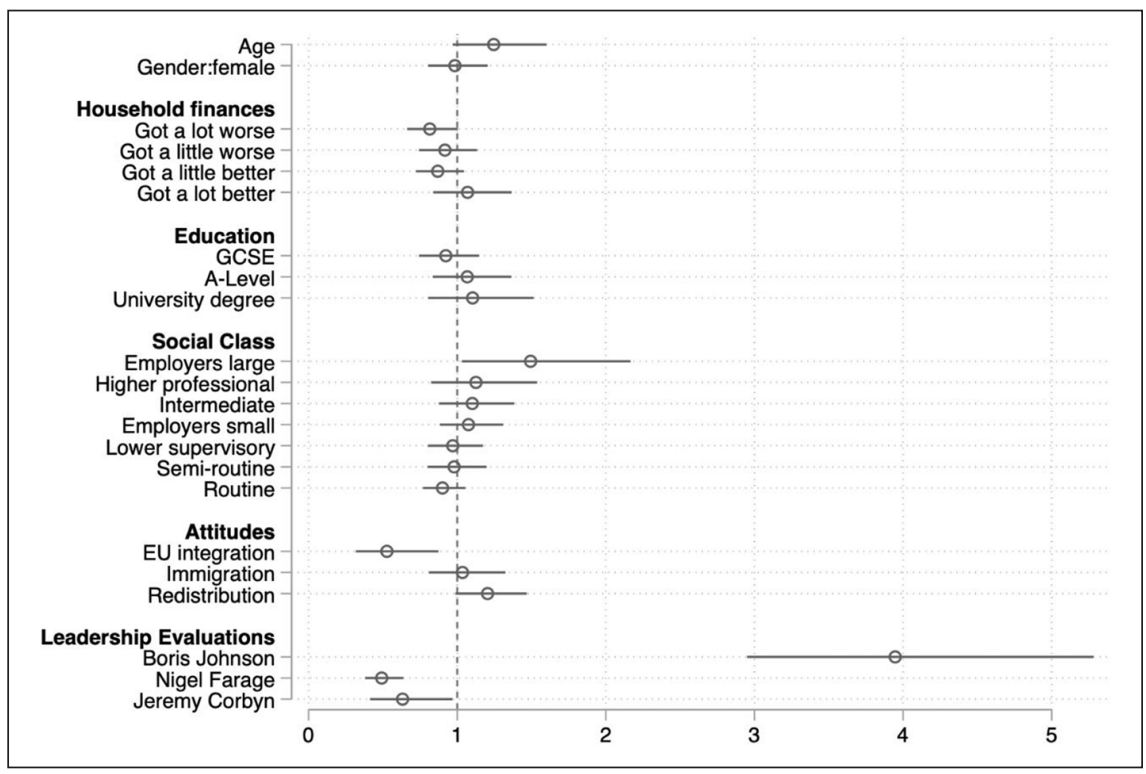

Figure 7. Coefficient Plot: Predictors of Brexit Party Switching to the Conservatives Between the EP Election and the 2019 General Election.

Coefficients are odds ratios; variables are standardized.

strategy and absorption of radical-right voters into the Conservative Party was to a substantial degree a result of the popularity of the Conservative leader with Brexit Party supporters.

Inevitably, people who approve Boris Johnson tend also to approve of Brexit. To further examine the robustness of this finding we therefore undertook two further sets of models, which are presented in the online appendix. We added further EU-related attitudes to our core model shown in Figure 7 (shown in online appendix Table A6). The first model included no EU attitudes and another added two additional Brexit attitudes, namely: 'do you support a second referendum' and 'if there is a referendum on the government's deal, what would you choose leave /remain'. These are the variables we think capture most clearly a respondent's preference for 'getting Brexit done'. In all models the Johnson effect remains remarkably solid and is attenuated to only a very small degree when these further measures of Brexit attitudes are added. Respondents' preference for a second referendum exerts a substantial impact on Conservative vote switching - but the Boris Johnson effect is still both very sizeable and substantially larger than the effect of second referendum preferences, with a smaller standard error.

A second set of robustness tests included other potential explanatory variables concerning perceptions of the government. These are themselves potentially endogenous to Johnson's election. If, for example, perceptions of the government change because of the appointment of a new leader it would seem harsh to control for them as though they were in some way unrelated to that appointment and thereby control away this potential aspect of Johnson's impact. Nonetheless, we conducted further models, shown in online appendix Table A7, which control for evaluations of the National Health Service (NHS), the economy, the cost of living, crime, education and immigration levels, as well as general government approval. The residual Johnson coefficient in these models could therefore 


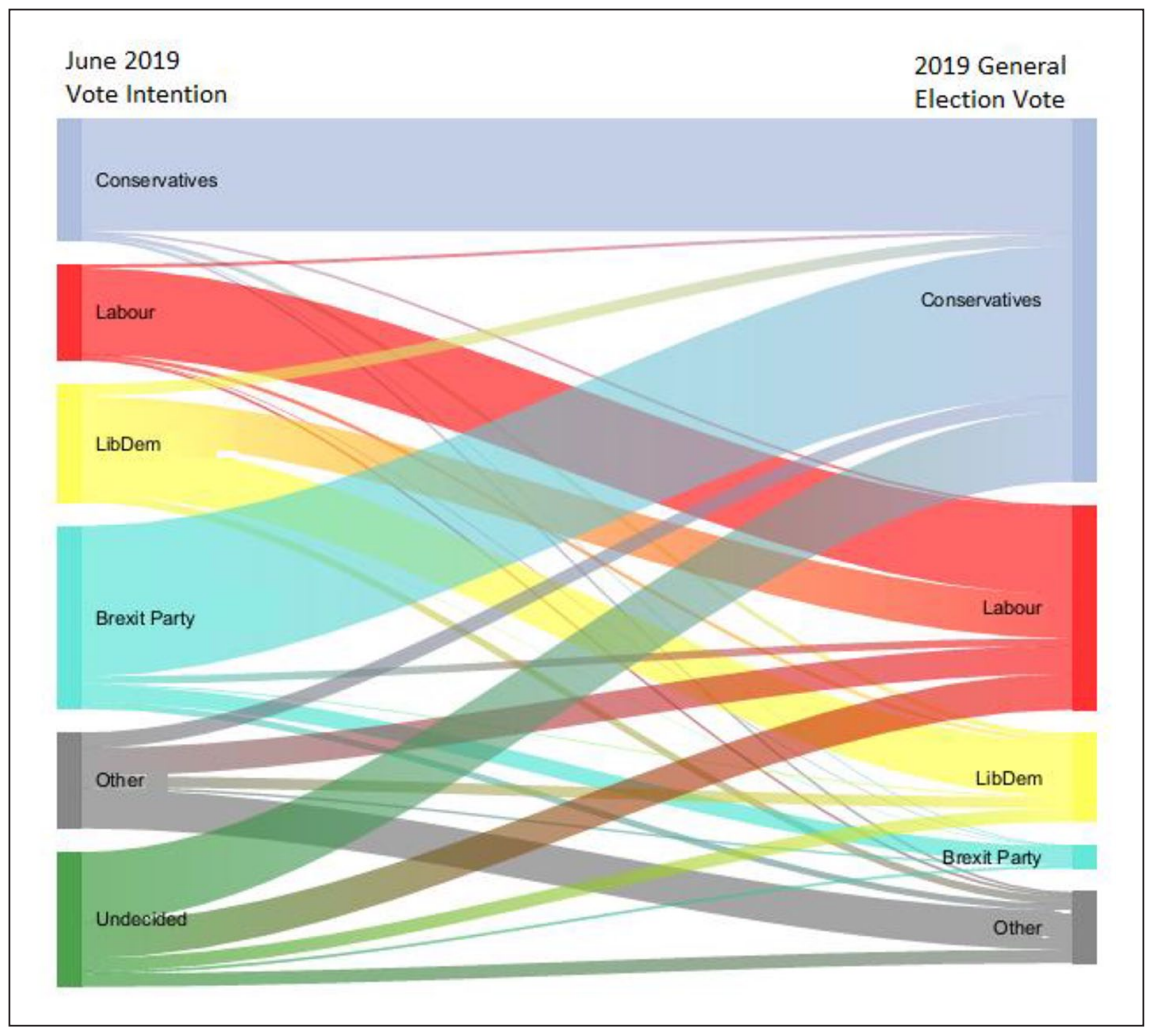

Figure 8. Flow of the Vote: 2019 European Elections to 2019 General Election.

be interpreted as a very 'minimalist' estimate of Johnson's direct effect on vote switching. Again, the Johnson effect is remarkably robust to this very wide range of model specifications. The entire battery of NHS, economy, cost of living, crime, education, immigration and general government approval had little effect on Johnson's impact which remained significant and substantial. The size of the coefficient drops very slightly (3.95-3.85) but it remains by far the largest effect in the model. Of the competence variables only 'cost of living' has a significant effect.

The result of this very effective appeal to Brexit Party supporters was a dramatic switching of European Parliament Brexit Party voters to the Conservatives in the December 2019 general election. Figure 8 shows the flow of votes between respondents' general election vote intention (post EP election), and their reported vote choice in December 2019.

Whereas a substantial proportion of 2014 UKIP votes had previously gone to the Labour Party in 2017 (see Figure 4), the Conservative Party was almost the sole beneficiary of Brexit Party voters who chose not to vote for the Brexit Party in the 2019 general election: among those who said following the EP elections that they intended to vote for the Brexit Party in any forthcoming general election no less than $82.5 \%$ switched to the Conservatives in December. Given the very high levels of continuity between UKIP and the Brexit Party - between the 2014 European Parliament and 2019 European Parliament elections, $88 \%$ of former 2014 European Parliament UKIP voters had switched to the 
Brexit Party - this shows how effectively the Conservative Party captured the support of the radical-right constituency that lay behind both UKIP's and the Brexit Party's shortlived electoral successes.

Our analysis has focused on the electoral relationship between Britain's radical-right parties and the mainstream Conservative Party. Of course, this was not the only important feature of the 2019 general election as a whole. The Conservatives also captured the votes of many Leave voters who had previously voted for the Labour Party (Fieldhouse et al., 2021), ${ }^{10}$ and more successfully united the Leave vote behind them in 2019 than Theresa May was able to achieve in 2017 (Green, 2021). This resulted in an increase in the partisan sorting of the electorate around Brexit between 2017 and 2019, but asymmetrically (Cutts et al., 2020; Green, 2021; Prosser, 2020). The Remain vote was more broadly distributed (to Labour, the Liberal Democrats, the Greens and the SNP in Scotland), and this asymmetry can be seen not only at the individual-level but also in how these votes translated to support at the constituency-level (Green, 2021). Labour was squeezed on both sides in a pincer movement between the Conservatives and, primarily, the Liberal Democrats. For example, Labour's vote share was substantially lower, and the Liberal Democrat's share higher, in wealthier constituencies and constituencies with more graduates, while Labour was squeezed by the Conservatives in Leave supporting, more deprived constituencies and constituencies with the highest proportions with no educational qualifications. One of the upshots of these changes was that while the Liberal Democrats increased their share by 4.1 percentage points nationally, they increased their vote share by just under 12 percentage points in the seats that Labour was targeting. The net result was a reduction of their final tally of MPs by one compared with 2017. These seat-vote inefficiencies played out from the multi-party nature of the competition for Remain voters.

\section{Conclusion}

How do centre-right parties successfully respond to the electoral threat and challenge from radical-right competitors? Competing on anti-immigration and Eurosceptic positions may deprive radical-right parties of their voters, but this may also have the effect of alienating more moderate centrist voters and increasing the electoral salience of those second-dimension issues. Hence, researchers ask whether mainstream parties should engage or disengage (Downs, 2012), hold, defuse or adopt (Bale et al., 2010), or take dismissive, accommodative or adversarial strategies (Abou-Chadi, 2016; Meguid, 2005, 2008; Meijers and Williams, 2019).

This article has focused on the highly successful accommodation strategy of the British Conservative Party within the context of this party's support for Britain's departure from the EU. This issue, highly polarized in Britain, had motivated voters to penalize the British Conservatives, particularly in second-order elections for the European Parliament in which Britain's radical-right parties (UKIP and the Brexit Party, respectively) topped the poll in both the 2014 and 2019 European Parliament elections. The Conservatives' subsequent ability to win these voters back, particularly in the 2019 general election, provides a valuable insight to a centre-right accommodative strategy in a majoritarian electoral system.

We demonstrate that while these voters were motivated by anti-immigration sentiment and Euroscepticism in these European Parliament elections, one of the most influential factors in their subsequent votes for the pro-Brexit Conservative Party in the 2019 general election was the personal appeal of the Conservative Party leader and Prime Minister, 
Boris Johnson. We contend that, given the particular importance of leadership to the voters of populist parties (Albertazzi and McDonnell, 2008), leadership effects can also be particularly significant in winning these voters by mainstream political parties. A populist charismatic leader can provide success for mainstream parties in competition with radical-right challenger parties. The Conservatives gained a majority of 80 seats in the 2019 general election, the largest Conservative majority since 1987 and $43.6 \%$ of the national vote - the highest percentage for any party since 1979. Consolidating leave voters behind the Conservatives resulted in the near electoral annihilation of the Brexit Party, who achieved just $2 \%$ overall.

The radical-right voters in Britain had been remarkably consistent, moving towards and away from the Conservative Party in first- and second-order elections. UKIP had risen in popularity in 2014 and 2015, largely at the expense of the Conservatives. Its effective electoral disappearance in the 2017 general election was then largely a result of the Conservatives reclaiming 2015 UKIP voters. The consequent emergence of Nigel Farage's new electoral vehicle - the Brexit Party - in the 2019 European Parliament elections was based on appealing to these same voters. The flow of the vote from UKIP to the Brexit Party is to a large degree mirrored by their demographic composition, but the emphasis was different: anger at the government's failure to carry out Brexit and increased disaffection with parliament motivated 2019 Brexit Party voters, rather than concern about EU immigration.

The electoral focus on these voters reflects the nature of political competition in realigned post-Brexit Britain where the extent of the polarization between Remain and Leave renders attempts to appeal across the Brexit divide too difficult to risk. The Conservatives therefore concentrated on developing a sufficient electoral base of Leave voters in Leave constituencies to compensate for any losses among Remain voters in Remain constituencies. As we have shown, the election of Boris Johnson as leader following Theresa's resignation following the fiasco of the 2019 European Parliament elections is consistent with this strategy. His cross-party appeal strengthened substantially the ability of the Conservative Party to attract Brexit Party supporters. The Conservatives won the 2019 election in part because they brought the politically marginalized radical-right constituency back into the mainstream. Unlike in proportional European electoral systems, where the $15 \%$ or so radical-right voters receive direct representation, these voters were only likely to receive effective representation in Britain through one or other of the established parties moving to engage with them. As a result, between 2015 and 2019 the Conservatives moved from being a pro-EU and socially liberal party under David Cameron to being a pro-Brexit and more socially Conservative Party led by a populist leader in Boris Johnson in 2019. A consequence of this strategy was the creation of a government that embodied both traditional Conservativism and the policies and appeals characteristic of populist, radical right, parties (a harder line on the EU, tough on immigration, strong on law and order). Only by aligning these two distinctive aspects of right-wing politics could a majority be effectively created once the unidimensional nature of party competition had been transformed through the Brexit process.

The ability of the Conservatives to win the support of Brexit Party voters was not the only factor explaining their success in the 2019 general election. Brexit Party voters - and other Leave voters - were crucial to their success. Our central narrative concerns how a party can unify one bloc of a polarized cross-cutting cleavage through policy and cross-party leader appeals so that, if its votes are sufficiently concentrated relative to the competition, it can win a majority under a first-past-the-post system. 
However, it would be unwise to assume that this is unique to the British system and cannot also generalize to PR systems. If a party in a more proportional system managed to unify voters on one side of an evenly split axis of competition, it might also win a majority (which, after all, is still possible in PR systems). The key factor influencing success in this respect is likely to be the degree to which the cross-cutting cleavage is evenly balanced. If an anti-EU, anti-immigration support bloc is a modest electoral minority then its voting power vote is always likely to lose out against a coalition of parties who derive their support from a larger section of the electorate. Moreover, while strategic positioning and populist leadership can produce electoral success, it mainstreams radical-right rhetoric and policies into politics. The contemporary Conservative Party is likely now wedded to UKIP/Brexit Party supporters who overwhelmingly voted to leave the EU. Many of these voters had voted Conservative in the years before 2015, but their evident willingness to defect means that they need to be attended to in order to maintain Conservative electoral preeminence. These voters are, therefore, important for understanding the Conservative Party's electoral fortunes in recent years and possibly their prospects in years to come. In extending their appeal to the radical-right constituency, the Conservatives have become more vulnerable in the centre. In 2019 various circumstances prevented this from undermining their electoral appeal, in particular the party splits of the Remain voters and the internally divided and weakened Labour Party. In future campaigns it is not clear that these circumstances will still be in evidence, and the endorsement of populist policies and a populist leader may prove more of a liability than an asset.

\section{Acknowledgements}

The authors are grateful to the anonymous reviewers and the Editor of Political Studies.

\section{Declaration of Conflicting Interests}

The author(s) declared no potential conflicts of interest with respect to the research, authorship and/or publication of this article.

\section{Funding}

The author(s) disclosed receipt of the following financial support for the research, authorship and/or publication of this article: We are grateful for funding from the Economic and Social Research Council for a European Parliament elections uplift to the main British Election Study grant (ES/S015671/1) that supported this research.

\section{ORCID iDs}

Geoffrey Evans (iD) https://orcid.org/0000-0003-0237-1481

Roosmarijn de Geus (iD https://orcid.org/0000-0003-3053-2123

\section{Supplemental Material}

Additional Supplementary Information may be found with the online version of this article.

Table A1: Models UKIP 2014 and Brexit Party 2019 - demographics model.

Table A2: Models UKIP 2014 and Brexit Party 2019 - attitudes model.

Table A3: Models UKIP2014 and Brexit Party 2019 - full model: demographics and attitudes.

Table A4: Models UKIP 2014 and Brexit Party 2019 - demographics model, household income instead of sociotropic retrospective economic evaluation.

Table A5: Switching BXP vote intention to Conservative vote (Figure 7).

Table A6: Switching BXP vote intention to Conservative vote - with additional Brexit variables. 
Table A7: Switching BXP vote intention to Conservative vote - with additional government handling variables.

Table A8: Variable descriptions for variables included in regression models.

Figure A1: Flow of the vote 2017-2019 for Leave and Remain voters.

\section{Notes}

1. Although this emphasis has itself been criticized: for Mudde (2007: 262) 'the key problem with the variable "charismatic leader" is the vagueness of the term' which means 'this explanation of support for populist parties is not open to empirical falsification' (van der Brug and Mughan, 2007: 44).

2. https://www.politico.eu/europe-poll-of-polls/united-kingdom/

3. We report effects for household finances in place of income (to maximize the samples), and also report the results using income (which show no differences and null effects) in Table A5 of the online appendix).

4. This can be seen by examining the impact of the primarily cultural orientations and preferences that underlie the choice of both parties by voters, and which completely account for education effects in models including both demographic and attitudinal variables. Compare online appendix Tables A1 and A3.

5. These differences are only found when using evaluations of the household economy over the past 12 months. If we replace this measure with reported household income, there are no significant effects in 2014 or 2019, which suggests that actual economic circumstances did not explain UK Independence Party (UKIP) or Brexit Party voting. A possible interpretation of these effects, therefore, is that economic perceptions were more closely tied to Brexit support in 2019, perhaps in comparison to the relatively greater effect of immigration preferences on UKIP voters in 2014, because in 2019 people who believed the Brexit vote in 2016 was having a negative impact on their household finances would be less likely to vote for the Brexit Party. The rather limited converse effects seen in 2014 were observed when Britain had not yet voted to leave the European Union (EU), so there was possibly a reverse attribution in process at that point.

6. This is all the more impressive because prior to this time UKIP's support had been subject to greater 'churn' than that of the major parties (Evans and Mellon, 2015).

7. Full descriptions of all items are given in the online appendix. The immigration variable includes measures of attitudes towards immigrants on both cultural and economic dimensions, although the latter is typically more important (De Rooij et al., 2018).

8. Note that the potential for the Brexit Party to increase its support at the expense of other parties in a general election was still very limited. The vast majority (80\%) of respondents who stated they will vote for the Brexit Party in a general election had also voted for the Brexit Party in the 2019 European elections. Most of the remaining $20 \%$ of the potential Brexit Party vote (17\%) comes from respondents who did not vote for any party in the European elections.

9. This raises the question of why more Conservatives, especially Remain voters, who evaluated Johnson negatively did not defect in 2019. The extent of this retention can be seen in the flow of the vote for Leave and Remain voters shown in online appendix Figure A1 (see also Fieldhouse et al., 2021). The Conservatives held onto a greater proportion of their - overall smaller proportion of - Remain voters than was the case for Labour and its Leave voters. Among the likely reasons for this resilience is that those Conservatives who voted Remain and who voted Conservative in 2017 were likely to represent especially loyal Conservatives. They had, after all, stayed with the Conservative Party in 2017 after the 2016 Brexit referendum, and under Theresa May's 'Brexit means Brexit' position in the 2017 general election. Furthermore, while they had voted Remain, their preferences about Euroscepticism were, on average, less Europhile in intensity than their Labour or Liberal Democrat voting counterparts, and they were more likely to find a Brexit position plus deal with the EU - which was still very much a promise then - a more palatable compromise (details available on request). Of course, as online appendix Figure A1 shows, the Conservatives did lose some support among their Remain voters to the Liberal Democrats. However, these vote losses failed to translate into seat gains for a party that generally struggles to win seats under the majoritarian electoral system, and which was especially true in terms of the dispersion in 2019. And in 2019, the Liberal Democrats also took votes from a poorly performing Labour Party that was also competing for Remain voters.

10. See also Figure A1 of the online appendix.

11. In W2, half the sample was asked the question listed in the table. The other half was asked: "Some say European Unification should be pushed further. Others say it has already gone too far. What is your opinion?" responses were on a 0-10 scale and were combined with the question listed in the table. 


\section{References}

Abou-Chadi T (2016) Niche Party Success and Mainstream Party Policy Shifts: How Green and Far-Right Parties Differ in Their Impact. British Journal of Political Science 46 (2): 417-436.

Adams JF and Somer-Topcu Z (2009) Policy Adjustment by Parties in Response to Rival Parties' Policy Shifts: Spatial Theory and the Dynamics of Party Competition in Twenty-Five Post-War Democracies. British Journal of Political Science 39 (1): 825-846.

Adams JF, Clark M, Ezrow L, et al. (2006) Are Niche Parties Fundamentally Different from Mainstream Parties? The Causes and the Electoral Consequences of Western European Parties' Policy Shifts, 19761998. American Journal of Political Science 50 (3): 513-529.

Adams JF, Merrill S III and Grofman B (2005) A Unified Theory of Party Competition: A Cross-national Analysis Integrating Spatial and Behavioral Factors. Cambridge: Cambridge University Press.

Albertazzi D and McDonnell D (2008) Twenty-First Century Populism: The Spectre of Western European Democracy. London: Palgrave Macmillan.

Art D (2011) Inside the Radical Right: The Development of Anti-immigrant Parties in Europe. Cambridge: Cambridge University Press.

Bale T, Green-Pedersen C, Krouwel A, et al. (2010) If You Can't Beat Them, Join Them? Explaining Social Democratic Responses to the Challenge from the Populist Radical Right in Western Europe. Political Studies 58 (3): 410-426.

Bornschier S and Kriesi H (2013) The Populist Right, the Working Class and the Changing Face of Class Politics. In: Rydgren J (ed.) Class Politics and the Radical Right. London: Routledge, pp. 10-30.

Cutts D, Goodwin M, Heath O, et al. (2020) Brexit, the 2019 General Election and the Realignment of British Politics. Political Quarterly 91: 7-23.

De Geus R and Ralph-Morrow E (2021) An Every Man, Not for Every Woman: Nigel Farage and the Radical Right Gender Gap. Journal of Elections, Public Opinion and Parties. Epub ahead of print 31 August. DOI: 10.1080/17457289.2021.1968410.

De Geus R and Ralph-Morrow E (2021) An Every Man, Not for Every Woman: Nigel Farage and the Radical Right Gender Gap. Journal of Elections, Public Opinion and Parties. Epub ahead of print 31 August. DOI: 10.1080/17457289.2021.1968410.

De Rooij E, Goodwin M and Pickup M (2018) A Research Note: The Differential Impact of Threats on Ethnic Prejudice Toward Three Minority Groups in Britain. Political Science Research and Methods 6 (4): 837-845.

de Lange SL (2012) New Alliances: Why Mainstream Parties Govern with Radical Right-Wing Populist Parties. Political Studies 60 (4): 899-918.

de Vries CE and Edwards EE (2009) Taking Europe to Its Extremes: Extremist Parties and Public Euroscepticism. Party Politics 15 (1): 5-28.

de Vries CE and Hobolt SB (2012) When Dimensions Collide: The Electoral Success of Issue Entrepreneurs. European Union Politics 13 (2): 246-268.

Dennison J and Goodwin M (2015) Immigration, Issue Ownership and the Rise of UKIP. Parliamentary Affairs 68 (1): $168-187$.

Dolezal M (2012) Restructuring the European Political Space: The Supply Side of European Electoral Politics. In: Kriesi H, Grande E and Dolezal M, et al. (eds) Political Conflict in Western Europe. Cambridge: Cambridge University Press, pp.127-150.

Downes J and Loveless M (2018) Centre Right and Radical Right Party Competition in Europe: Strategic Emphasis on Immigration, Anti-Incumbency and Economic Crisis. Electoral Studies 54: 148-158.

Downes J, Loveless M and Lam A (2021) The Looming Refugee Crisis in the EU: Right-Wing Party Competition and Strategic Positioning. Journal of Common Market Studies. Epub ahead of print 16 February. DOI: 10.1111/jcms.13167.

Downs A (1957) An Economic Theory of Democracy. New York: Harper.

Downs WM (2012) Political Extremism in Democracies: Combating Intolerance. Palgrave Macmillan, New York: Springer.

Eatwell R (2018) Charisma and the Radical Right. In: Rydgren J (ed.) The Oxford Handbook of the Radical Right. Oxford: Oxford University Press, pp.251-268.

Evans G and Mellon J (2015) The Political Popularity Contest. Significance 12 (2): 6-8.

Evans G and Mellon J (2016) Working Class Votes and Conservative Losses: Solving the UKIP Puzzle. Parliamentary Affairs 69 (2): 464-479.

Evans G and Menon A (2017) Brexit and British Politics Cambridge: Polity Press.

Evans G and Mellon J (2019) Immigration, Euroscepticism, and the Rise and Fall of UKIP. Party Politics 25 (1): 76-87. 
Evans G and Schaffner F (2019) Brexit Identity vs Party Identity. In: Menon A and Wager A (eds) Brexit \& Public Opinion 2019. London: UKICE, pp.18-19.

Evans G and Tilley J (2017) The New Politics of Class: The Political Exclusion of the British Working Class. Oxford: Oxford University Press.

Fieldhouse E, Green J, Evans G, et al. (2020a) British Election Study Internet Panel: Waves 1-19. https:// Britishelectionstudy.com

Fieldhouse E, Green J, Evans G, et al. (2020b) Electoral Shocks: The Volatile Voter in a Turbulent World. Oxford: Oxford University Press.

Fieldhouse E, Green J, Evans G, et al. (2021) Volatility, Realignment and Electoral Shocks: Brexit and the UK General Election of 2019. SSRN Working Paper. DOI: 10.2139/ssrn.3764477.

Ford R and Goodwin M (2014) Revolt on the Right. London: Routledge.

Goodwin M and Milazzo C (2015) UKIP: Inside the Campaign to Redraw the Map of British Politics. Oxford: Oxford University Press.

Green J (2021) Breaking the Deadlock: Britain at the Polls, 2019. In: Allen N and Bartle J (eds) Manchester: Manchester University Press, pp. 174-197.

Harmel R and Svåsand L (1997) The Influence of New Parties on Old Parties' Platforms: The Case of the Progress Parties and Conservative Parties of Denmark and Norway. Party Politics 3 (3): 315-340.

Hobolt S, Leeper TJ and Tilley J (2021) Divided by the Vote: Affective Polarization in the Wake of the Brexit Referendum. British Journal of Political Science 51: 1476-1493.

Laver M and Sergenti E (2011) Party Competition: An Agent-Based Model. Princeton, NJ: Princeton University Press.

Meguid BM (2005) Competition between Unequals: The Role of Mainstream Party Strategy in Niche Party Success. American Political Science Review 99 (3): 347-359.

Meguid BM (2008) Party Competition between Unequals: Strategies and Electoral Fortunes in Western Europe. Cambridge: Cambridge University Press.

Meijers MJ (2017) Contagious Euroscepticism? The Impact of Eurosceptic Support on Mainstream Party Positions on European Integration. Party Politics 23 (4): 413-423.

Meijers MJ and Williams CJ (2019) When Shifting Backfires: The Electoral Consequences of Responding to Niche Party EU Positions. Journal of European Public Policy 27 (10): 1506-1525.

Mellon J, Evans G, Fieldhouse E, et al. (2018) Brexit or Corbyn? Campaign and Inter-Election Vote Switching in the 2017 UK General Election. Parliamentary Affairs 71 (4): 719-737.

Michel E, Garzia D, Ferreira da Silva F, et al. (2020) Leader Effects and Voting for the Populist Radical Right in Western Europe. Swiss Political Science Review 26 (3): 273-295.

Mudde C (2007) Populist Radical Right Parties. Cambridge: Cambridge University Press.

Muis J and Immerzeel T (2017) Causes and Consequences of the Rise of Populist Radical Right Parties and Movements in Europe. Current Sociology Review 65 (6): 909-930.

Norris P and Inglehart R (2019) Cultural Backlash: Trump, Brexit and Authoritarian Populism. Cambridge: Cambridge University Press.

Odmalm P and Bale T (2015) Immigration into the mainstream: Conflicting ideological streams, strategic reasoning and party competition. Acta Politica 50: 365-378.

Pardos-Prado S (2015) How Can Mainstream Parties Prevent Niche Party Success? Centre-Right Parties and the Immigration Issue. The Journal of Politics 77 (2): 352-367.

Prosser C (2020) The End of the EU Affair: The UK General Election of 2019. West European Politics 23: $1-12$.

Rabinowitz G and Macdonald SE (1989) A Directional Theory of Issue Voting. American Political Science Review 83 (1): 93-121.

Reif K, Schmitt H and Norris P (1997) Second-Order Elections. European Journal of Political Research 31 (1-2): 109-124.

Rydgren J (2008) Immigration Sceptics, Xenophobes or Racists? Radical Right-Wing Voting in Six West European Countries. European Journal of Political Research 47 (6): 737-765.

van der Brug W and Mughan A (2007) Charisma, Leader Effects and Support for Right-Wing Populist Parties. Party Politics 13 (1): 29-51.

Van Spanje J (2010) Contagious Parties: Anti-Immigration Parties and Their Impact on Other Parties' Immigration Stances in Contemporary Western Europe. Party Politics 16 (5): 563-586.

Wagner M and Meyer TM (2017) The Radical Right as Niche Parties? The Ideological Landscape of Party Systems in Western Europe, 1980-2014. Political Studies 65 (1): 84-107.

Williams C and Spoon J (2015) Differentiated Party Response: The Effect of Euroskeptic Public Opinion on Party Positions. European Union Politics 16 (2): 176-193. 
Zhirkov K (2014) Nativist but Not Alienated: A Comparative Perspective on the Radical Right Vote in Western Europe. Party Politics 20 (2): 286-296.

\section{Author Biographies}

Geoffrey Evans, FBA, is official fellow in Politics Nuffield College and professor in the Sociology of Politics, University of Oxford. He is a co-director of the British Election Study.

Roosmarijn de Geus is a lecturer in Comparative Politics at the University of Reading, UK. Prior to this, she was a postdoctoral researcher at the Nuffield Politics Research Centre at Nuffield College, University of Oxford.

Jane Green is professor of Political Science and British Politics at Nuffield College, University of Oxford; director of the Nuffield Politics Research Centre; and a co-director of the British Election Study. 